\title{
HUBUNGAN ANTARA KOMUNIKASI INTERPERSONAL DAN KERJASAMA TIM DENGAN EFEKTIVITAS MANAJERIAL KEPALA SEKOLAH MENENGAH ATAS SWASTA WILAYAH JAKARTA TIMUR
}

\author{
Raden Heni Muljani*
}

\begin{abstract}
This study aims to determine the relationship between (1) interpersonal communication with managerial effectiveness, (2) teamwork with managerial effectiveness, and (3) interpersonal communication and teamwork together with managerial effectiveness. The research method used in this research is survey with correlation approach. In the sample size was 61 respondents taken by proportional random sampling. The study was conducted to senior high school principals in East Jakarta. The results of the study pointed out that: (1) there is a positive relationship between interpersonal communication with managerial effectiveness, (2) there is a positive relationship between teamwork with managerial effectiveness and (3) there is a positive relationship between interpersonal communication and teamwork together with managerial effectiveness.
\end{abstract}

Keywords : Interpersonal communication, teamwork, and managerial effectiveness

\section{PENDAHULUAN}

Dalam konteks otonomi daerah, pelimpahan wewenang pengelolaan pendidikan dari pemerintah pusat kepada pemerintah daerah digagas dan diawali dengan diberlakukannya UU Nomor 22 tahun 1999 dan disempurnakan dengan UU Nomor 32 tahun 2004 tentang Pemerintah Daerah, berisi tentang penyerahan sejumlah wewenang yang semula menjadi urusan Pemerintah Pusat kepada Pemerintah Daerah, termasuk di dalamnya pengelolaan bidang pendidikan. Pelimpahan wewenang ini diteruskan dengan dikeluarkan UU Nomor 33 tahun 2004 tentang Perimbangan Keuangan Antara Pemerintahan Pusat Dan Pemerintahan Daerah yang bertujuan memberdayakan dan meningkatkan kemampuan perekonomian daerah, menciptakan sistem pembiayaan daerah yang adil, transparan dan bertanggung jawab. Kebijakan pendidikan yang semula bersifat sentralisasi berubah menjadi desentralisasi yaitu penyerahan wewenang dari pemerintah pusat kepada daerah otonomi untuk mengatur dan mengurus urusan pemerintahan dalam sistem Negara Kesatuan Republik Indonesia.

Untuk mengimplementasikan manajemen berbasis sekolah secara efektif dan efisien,kepalasekolah perlu memiliki pengetahuan kepemimpinan, perencanaan dan pandangan yang luas tentang sekolah dan pendidikan. Wibawa kepala sekolah harus ditumbuhkembangkan dengan meningkatkan sikap kepedulian, semangat belajar, disiplin kerja, keteladanan dan hubungan manusiawi sebagai modal perwujudan iklim kerja yang kondusif. Lebih lanjut, kepala sekolah dituntut untuk melakukan fungsinya sebagai manajer sekolah dalam meningkatkan proses belajar mengajar, dengan melakukan supervisi kelas, membina dan memberikan saran-saran positif kepada guru. Disamping itu kepala sekolah juga harus melakukan tukar pikiran

\footnotetext{
* Guru Sekolah Menengah Atas Pusaka 1 Jakarta
} 
sumbang saran, dan studi banding antar sekolah untuk menyerap kiat-kiat kepemimpinan dari kepala sekolah yang lain.

Departemen Pendidikan Nasional memperkirakan 70 persen dari 250 ribu kepala sekolah di Indonesia tidak kompeten. Berdasarkan ketentuan Departemen, setiap kepala sekolah harus memenuhi lima aspek kompetensi, seperti yang dijelaskan dalam lampiran Peraturan Pemerintah Nomor 13 Tahun 2007 Tentang Standar Kepala Sekolah/Madrasah. Kompetensi kepala sekolah antara lain adalah (1) kompetensi kepribadian (2) kompetensi manajerial (3) kompetensi kewirausahaan (4) kompetensi supervisi dan (5) kemampuan sosial. Dari beberapa temuan dan fakta yang kita hadapi bahwa masih sangat sedikit kepala sekolah yang memiliki kompetensi yang sesuai dengan Peraturan Menteri Pendidikan Nasional Nomor 13 Tahun 2007 tentang Kompetensi Kepala Sekolah. Sementara kepala sekolah merupakan pemimpin yang menjadi ujung tombak keberhasilan suatu sekolah dalam mencapai tujuan organisasi. Dengan demikian peneliti sangat tertarik untuk melakukan penelitian mengenai kompetensi kepala sekolah melalui efektivitas manajerial kepala sekolah sehingga tujuan sekolah dapat tercapai sesuai dengan perencanaan.

\section{Efektivitas Manajerial}

Efektivitas manajerial didefinisikan secara berdeda-beda oleh para ahli, Laurie J. Mullins (2005:260) menjelaskan bahwa, "effectiveness is concerned with 'doing the right things', and relates to outputs of the job and what the manager actually achieves". Efektivitas menekankan kepada 'doing the right things', yaitu melakukan sesuatu yang benar dan dihubungkan kepada hasil (output) dari pekerjaan dan apa yang sebenarnya dicapai oleh seorang manajer. Untuk mencapai efektivitas, manajer harus memperhatikan hasil dari sebuah pekerjaan terhadap kinerja untuk mendapatkan hasil yang semaksimal mungkin dengan mengoptimalkan penggunaan sumber daya, peningkatan keuntungan, dan pencapaian tujuan organisasi.

James L. Gibson, et al. (2009:13) dalam bukunya "Organization Behavior, Structure, Processes" menjabarkan perspektif efektivitas sebagai berikut, "managers and others who have interests in whether organizations perform effectively can focus on one or all of three perspectives". Manajer dan lainny a yang tertarik dalam menilai efektivitas organisasi dapat memfokuskan kepada satu atau seluruh dari ketiga perspektif efektivitas. "The most basic level, individual effectiveness, emphasizes the task performance of specific employees or members of the organization." Tingkatan yang paling dasar adalah efektivitas individu, menekankan pada prestasi tugas individu atau anggota organisasi. Manajer secara terus menerus menilai efektivitas individu bawahannya untuk dijadikan penilaian terhadap kenaikan gaji, promosi atau bonus. Tingkat selanjutnya adalah efektivitas kelompok, "...group effectiveness, is simply the sum of the contributions of all its members."7 Efektivitas kelompok yang merupakan penjumlahan dari kontribusi seluruh anggota organisasi, sedangkan tingkatan selanjutnya adalah efektivitas organisasi, "...organizational effectiveness consists of individual and group effectiveness. Efektivitas organisasi yang terdiri atas efektivitas individu dan efektivitas kelompok. Efektivitas organisasi akan tercapai dengan adanya sinergi dan kerja sama antara anggota dan kelompok sehingga menghasilkan efektivitas organisasi yang lebih tinggi dari sekedar penjumlahan dari masing-masing efekivitas.

Dijelaskan juga mengenai manajer efektif dalam buku "Organizational Behavior oleh John R. Schermerhorn Jr., et al.,(2011:14) yaitu, “...an effective manager-one whose team 
or work unit or total organization consistently achieves its performance goals while members remain capable, enthusiastic, and satisfied in their job". Manajer efektif adalah seorang yang memiliki tim atau unit kerja atau keseluruhan organisasi yang secara terus menerus melakukan kegiatannya untuk mencapai tujuan kinerja sedangkan anggotanya tetap mampu, antusias, dan merasa puas dengan pekerjaan mereka. Definisi manajer efektif ini menekankan kepada dua kunci hasil (outcomes) atau variable bebas yang penting dalam perilaku organisasi. Hasil yang pertama adalah kinerja tugas (task performance), sebagai kualitas dan kuantitas dari produk atau jasa yang dihasilkan oleh individu, tim atau unit kerja, atau organisasi secara keseluruhan. Hasil yang kedua adalah kepuasan kerja (job satisfaction), hal ini mengindikasikan bagaimana seseorang yang bekerja dalam organisasi tersebut merasakan kepuasan terhadap pekerjaan mereka dan aturan kerja.

efektivitas manajerial menurut Colin P. Silverthorne (2005:121) "managerial effectiveness is based on shared values, the organizational culture, and the fit between them. Efektivitas manajerial didasarkan pada membagi nilai-nilai, budaya organisasi, dan kecocokan di antara mereka. Sebuah model konseptual prediktor efektivitas manajerial dalam konteks global adalah: (1) kepribadian (personality), (2) Pengalaman (experience), (3) Kemampuan manajerial (managerial capability). (4) Peran Manajerial (managerial role). (5) kompleksitas global.

Berdasarkan uraian di atas dapat disintesiskan bahwa efektivitas manajerial adalah keberhasilan seseorang dalam mengelola organisasi melalui ketepatan dalam pemilihan dan pengalokasian sumber daya, menciptakan komitmen dan kepuasan pengikut, serta melakukan pengawasan dalam mencapai tujuan organisasi. Adapun indikator dari efektivitas manajerial adalah pencapaian tujuan (goal attainment), alokasi sumber daya (allocation of resources), memberikan motivasi (motivation), pelaksanaan kerja dengan benar (doing the right things), melakukan kerjasama (coordination), memonitoring (monitoring), dan evaluasi hasil kerja (evaluation).

\section{Komunikasi Interpersonal}

Schermerhorn (2011:22) dalam bukunya "Handbook of Communication Skills" d ijelaskan tentang komunikasi interpersonal yaitu: In interpersonal communication, we are bombarded by a constant stream of sensory stimulation, in the form of noises, sights, smells, tastes, and tactile sensations. While bodily olfaction has a very important communicative function that can affect the relationships we develop with others. Dalam komunikasi interpersonal, kita dibombardir oleh aliran konstan stimulasi sensorik, dalam bentuk suara, pemandangan, bau, rasa, dan sensasi taktil. Sementara penciuman tubuh memiliki fungsi komunikasi yang sangat penting yang dapat mempengaruhi perkembangan hubungan kita dengan orang lain

Komunikasi interpersonal juga didefinisikan oleh John M. Ivancevich, Robert Konopaske dan Michael T. Matteson (2008:140) sebagai berikut: Within an organization, communication flows from individual to individual in a variety of ways, from face-to-face and group settings to instant messaging and videoconferencing. Such flows are termed interpersonal communication and can vary from direct orders to casual expressions. Interpersonal behavior could not exist without interpersonal communication. Dalam sebuah organisasi, komunikasi mengalir dari individu ke individu dalam berbagai cara. Dari tatap muka dan aturan kelompok sampai pesan singkat dan pertemuan video. Arus seperti ini disebut komunikasi interpersonal dan dapat bervariasi dari perintah langsung sampai pada ekspresi umum. Perilaku interpersonal tidak bisa terjadi tanpa adanya komunikasi interpersonal. 
Definisi lain mengenai komunikasi interpersonal dikemukakan oleh Beebe (1999:7) yaitu, "interpersonal communication is a special form of human communication that occurs when we interact simultaneously with another person and mutually influence each other, usually for the purpose of managing relationship." Komunikasi interpersonal merupakan bentuk komunikasi khusus manusia yang terjadi pada saat kita berinteraksi dengan orang lain dan memberikan keuntungan kepada kedua belah pihak, bertujuan untuk menjalin hubungan. Sedangkan menurut Judy C Pearson et al.(2008:19), "interpersonal communication is the process of using messages to generate meaning between at least two people in a situation that allows mutual opportunities for both speaking and listening." 40 Komunikasi interpersonal adalah proses menggunakan pesan untuk menghasilkan makna paling sedikit antara dua orang dalam situasi yang memungkinkan bagi keduanya untuk saling berbicara dan mendengarkan.

Komunikasi interpersonal didefinisikan oleh Slocum dan Hellriegel (2009:226) sebagai, "interpersonal communication refers to a limited number of participants who (1) are usually in proximity to each other, (2) use many sensory channels, and (3) are able to provide immediate feedback." Komunikasi interpersonal merujuk kepada jumlah partisipan yang terbatas (1) selalu saling berhubungan, (2) menggunakan banyak saluran sensor, dan (3) dapat memberikan umpan balik segera. Komunikasi antara manajer dengan pegawainya dalam sebuah organisasi termasuk komunikasi interpersonal. Komunikasi yang efektif dengan karyawan yang merupakan bagian dari kepemimpinan memiliki sedikitnya empat karakteristik dasar, yaitu keterbukaan, dukungan, memotivasi dan kekuasaan.

Dari uraian di atas dapat disintesiskan bahwa komunikasi interpersonal adalah proses pertukaran informasi antara dua orang dengan maksud memotivasi dan memberi pengaruh terhadap perilaku dalam mencapai tujuan organisasi.

\section{Kerjasama Tim}

Thomas Juli (2011:36) dalam bukunya "Leadership Principles for Project Success" menjelaskan mengenai kerjasama tim sebagai berikut:Teamwork is more than the sum of individual contributions on the team. Teamwork is the symbiosis among all individual teammembers. It can thus take the team as a whole, as one unit, to a higher level of performance. This is why team building is so valuable and has to be on the map of every project leader. Kerjasama tim adalah lebih dari sekedar jumlah kontribusi dari setiap anggota tim. Kerjasama tim merupakan simbiosis antara seluruh anggota tim. Hal tersebut dapat menjadikan tim secara utuh, sebagai sebuah unit, menuju level kinerja yang tinggi. Hal ini kenapa perkembangan tim begitu sangat berarti dan menjadi peta bagi setiap pemimpin proyek.

Dalam buku "Organizational Behavior: Human Behavior at Work", John W. Newstrom dan Keith Davis (2002:318) menjelaskan teamwork sebagai, "where their work is interdependent, they act as a task team and seek to develop a cooperative state called teamwork" Dimana mereka bekerja dengan adanya saling ketergantungan, mereka bertindak sebagai sebuah tim kerja dan mengembangkan kerjasama disebut kerjasama tim. Dua Kriteria bagi tim kerja di jelaskan oleh Kreitner dan kinicki (2010:310) bahwa, ${ }^{3}$ two effectiveness criteria for work teams: performance and viability. ${ }^{177}$ Dua kriteria keefektivitasan bagi tim kerja adalah kinerja (performance) dan viability. Dijelaskan pula bahwa team viability is defined as team members' satisfaction and continued willingness to contribute. Viability Tim didefinisikan sebagai kepuasan anggota tim dan keinginan untuk melanjutkan kontribusinya/keterlibatannya dalam tim. 
Sedangkan menurut John R. Schermerhorn Jr., et al. (2011:163), ...effective team as one that achieves high levels of task performance, member satisfaction, and team viability. Tim yang efektif menciptakan ketercapaian kinerja di level yang tinggi, kepuasan anggota, dan kelangsungan hidup tim. Dalam hal kinerja (task performance), tim yang efektif akan mencapai hasil kerja yang sesuai dengan standar yang telah ditetapkan dalam hal kualitas, kuantitas dan ketepatan waktu. Tim dikatakan efektif jika anggota tim merasakan tingkat kepuasan yang tinggi (member satisfaction), anggota percaya terhadap partisipasinya dan pengalamannya adalah positif serta dapat memenuhi kebutuhan atau kepuasan diri. Sedangkan dalam hal kelangsungan hidup (team viability), anggota dalam tim yang efektif akan merasa cukup puas untuk melanjutkan bekerja dengan baik bersama-sama dengan timnya untuk masa yang akan datang. Berdasarkan uraian di atas dapat disintesiskan bahwa kerjasama tim adalah tindakan bersama yang bersinergi oleh sekumpulan individu dalam menyelesaikan tugas-tugas dan permasalahan organisasi untuk mencapai tujuan.

\section{METODE}

Penelitian ini dilakukan pada Sekolah Menengah Atas Swasta di Wilayah Jakarta Timur. Waktu yang diperlukan dalam penyelesaian penelitian diperkirakan maksimum 4 (empat) bulan, dilaksanakan pada bulan April 2012 sampai dengan Juli 2012. Metode Penelitian yang digunakan dalam melakukan penelitian ini adalah metode survey dengan pendekatan korelasional. Dalam penelitian ini populasi terjangkaunya adalah Kepala Sekolah Menengah Atas Swasta wilayah Jakarta Timur sebanyak 72 orang. Ukuran sampel yang digunakan adalah 61 Kepala Sekolah Menengah Atas wilayah Jakarta Timur. Data penelitian didapat dengan menggunakan instrument. Teknik analisis data penelitian dilakukan dengan statistik deskriptif, uji statistik sederhana dan korelasi sederhana, uji statistik regresi ganda dan korelasi ganda.

\section{HASIL PENELITIAN DAN PEMBAHASAN}

\section{Hubungan Komunikasi Interpersonal dengan Efektivitas Manajerial}

Dalam pembuktian hipotesis pertama ternyata terdapat hubungan positif antara komunikasi interpersonal dengan efektivitas manajerial. Dengan demikian dapat ditafsirkan bahwa semakin baik komunikasi interpersonal maka efektivitas manajerial akan meningkat. Sebaliknya, semakin buruk komunikasi interpersonal maka efektivitas manajerial akan menurun. Hal ini sesuai dengan teori yang dikemukakan oleh V. G. Kondalkar (2007:193) yang menyatakan bahwa, "effective management is an output of effective communication. Poor communication or ineffective communication is a source of frustration, interpersonal conflict and stress." Manajemen yang efektif merupakan hasil dari komunikasi yang efektif. Komunikasi yang miskin atau komunikasi yang tidak efektif merupakan sumber dari frustasi, konflik interpersonal dan stress. Dengan demikian jelaslah bahwa terdapat hubungan positif antara komunikasi interpersonal dengan efektivitas manajerial.

\section{Hubungan Kerjasama Tim dengan Efektivitas Manajerial}

Dalam pembuktian hipotesis kedua ternyata terdapat hubungan positif antara kerjasama tim dengan efektivitas manajerial. Dengan demikian dapat dijelaskan bahwa semakin baik kerjasama tim akan meningkatkan efektivitas manajerial. Begitu pula sebaliknya menurunnya kerjasama tim akan menurunkan efektivitas manajerial. Seperti dijelaskan oleh Colquitt (2009:407) bahwa, "the 
effectiveness of organizations depends to a large extent on the activities and interactions that occur within teams as they move toward their task-related objectives." Efektivitas organ isasi tergantu ng kepada sebagian besar kegiatan dan interaksi yang terjadi dalam tim ketika mereka bergerak menuju tugas yang berhubungan dengan tujuan mereka.

Menurut John R. Schermerhorn Jr., et al., (2011:14) manajer yang efektif adalah, “...an effective manager-one whose team or work unit or total organization consistently achieve its performance goals while members remain capable, enthusiastic, and satisfied in their job". Manajer efektif adalah seorang yang memiliki tim atau unit kerja atau keseluruhan organisasi yang secara terus menerus melakukan kegiatannya untuk mencapai tujuan kinerja dimana anggotanya tetap mampu, antusias, dan merasa puas dengan pekerjaan mereka. Dengan demikian jelaslah bahwa terdapat hubungan positif antara kerjasama tim dengan efektivitas manajerial.

\section{Hubungan Komunikasi Interpersonal dan Kerjasama Tim secara Bersama-sama dengan Efektivitas Manajerial}

Dalam pembuktian hipotesis ketiga bahwa terdapat hubungan positif antara komunikasi interpersonal dan kerjasama tim secara bersama-sama dengan efektivitas manjerial. Dengan demikian semakin baik komunikasi interpersonal dan kerjasama tim secara bersama-sama akan meningkatkan efektivitas manajerial yang semakin baik pula. Dan sebaliknya jika komunikasi interpersonal dan kerjasama tim secara bersama-sama menurun, maka efektivitas manajerial juga akan menurun. Abraham (2006:515) menemukan bahwa terdapat hubungan antara komunikasi interpersonal dan kerjasama tim dengan efektivitas manajerial dalam buku "A Handbook of Communication Skills' bahwa, "...that companies often identify a variety of competencies as essential for managerial effectiveness, such as communication skills, a propensity for risk taking, and team working.' perusahaan sering mengidentifikasi berbagai kompetensi yang penting untuk efektivitas manajerial, seperti kemampuan komunikasi, kecenderungan untuk mengambil risiko, dan kerja tim.

Dijelaskan pula oleh S. Shajahan dan Linu (2004:148) sebagai berikut : ...the manajerial effectiveness will depend increasingly on his skill in collection, collection and communication of information and in ensuring its optimum use in coordination with people. Whatever the colour of style, a leader should motivate his team, creating the resources to help it perform well and achieve. Efektivitas manajerial akan tergantung pada keahliannya dalam mengumpulkan dan mengkomunikasikan informasi dan mempergunakannya untuk berkoordinasi dengan orang (kerjasama tim) secara optimal. Apapun warna atau gaya seorang pemimpin harus memotivasi timnya, menciptakan sumber daya untuk membantu pencapaian tujuan dengan baik. Dalam pencapaiannya, manajer harus mengenal dan memahami bawahannya untuk pencapaian tujuan dengan pembinaan dan arahan yang baik.

Ditegaskan pula oleh Mullins (2005:260), "the biggest contribution to effectiveness came from first, communicating and second, human resource management ${ }^{19}$ Kontri busi terbesar dalam efe ktivitas yang pertama adalah komunikasi dan kedua adalah manajemen sumber daya manusia. Dengan demikian jelaslah bahwa terdapat hubungan positif antara komunikasi interpersonal dan kerjasama tim secara bersama-sama dengan efektivitas manajerial. 


\section{PENUTUP}

\section{Kesimpulan}

Dari hasil perhitungan dan pengujian hipotesis, maka penelitian ini dapat disimpulkan sebagai berikut :

1. Terdapat hubungan positif antara komunikasi interpersonal dengan efektivitas manajerial, artinya semakin tinggi komunikasi interpersonal kepala sekolah maka semakin meningkat efektivitas manajerial kepala sekolah. Sedangkan jika komunikasi interpersonal kepala sekolah menurun maka efektivitas manajerial kepala sekolah akan menurun pula.

2. Terdapat hubungan positif antara kerjasama tim dengan efektivitas manajerial, artinya semakin tinggi kerjasama tim kepala sekolah maka akan semakin meningkat efektivitas manajerial kepala sekolah. Begitu pula sebaliknya jika kerjasama tim kepala sekolah menurun, maka efektivitas manjerial kepala sekolah pun akan menurun.

3. Terdapat hubungan positif secara bersama-sama antara komunikasi interpersonal dan kerjasama tim dengan efektivitas manajerial. Artinya semakin tinggi komunikasi interpersonal dan kerjasama tim kepala sekolah secara bersama-sama akan meningkatkan efektivitas manajerial kepala sekolah. Dan sebaliknya semakin menurun komunikasi interpersonal dan kerjasama tim kepala sekolah secara bersama-sama akan mengakibatkan menurunnya efektivitas manajerial kepala sekolah. 


\section{Saran}

Berdasarkan hasil penelitian dan implikasi, maka dalam rangka meningkatkan komunikasi interpersonal dan kerjasama tim direkomendasikan beberapa langkah tindak lanjut sebagai berikut:

1. Diharapkan para kepala sekolah khususnya di wilayah Jakarta Timur dan wilayah DKI Jakarta pada umumnya untuk meningkatkan kemampuan komunikasi interpersonal dan kerjasama timnya guna meningkatkan efektivitas manajerial kepala sekolah.

2. Diharapkan pemerintah tingkat suku dinas untuk mulai memperhatikan faktor komunikasi interpersonal dan kerjasama tim kepala sekolah dalam meningkatkan efektivitas manajerial kepala sekolah, tidak hanya memperhatikan kemampuan kognitif kepala sekolah saja.

3. Diharapkan adanya kegiatan berupa pelatihan atau pembinaan bagi kepala sekolah dengan memberikan pengetahuan untuk meningkatkan komunikasi interpersonal dan kerjasama tim dalam rangka meningkatkan efektivitas manajerial kepala sekolah.

\section{DAFTAR RUJUKAN}

Beebe, Steven A. Beebe, Susan J. and Redmond Mark V. Interpersonal Communication: Relating to Others. USA: Allyn \& Bacon, 1999.

Colquitt, Jason A. Lepine, Jeffery A. and Wesson Michael J. Organizational Behavior: Improving Performance and Commitment in the Workplace. Boston: McGraw-Hill, 2009.

Daft, Richard L. New Era of Management. Canada: Cengage Learning, 2010.

Gibson, James L. et al. Organizations: Behavior, Structure, Processes. New York: McGrawHill, 2009.

Greenberg, Jerald. Managing Behavior in Organizations. New Jersey: Pearson Education, 2010.

Hargie, Owen and Dickson, David. Skilled Interpersonal Communication: Research, Theory and Practice. New York: Routledge, 2005.

Ivancevich, John M. Konopaske, Robert. and Matteson, Michael T. Organizational Behavior and Management. New York: McGraw-Hill, 2008.

Juli, Thomas. Leadership Principles for Project Success . Boca Raton: CRC Press, 2011.

Kondalkar, V.G. Organizational Behavior. New Delhi: New age International, 2007.

Kreitner, Robert. and Kinicki, Angelo. Organization Behavior. New York: McGrawHill, 2010.

Luthans, Fred. Organizational Behavior. New York : McGraw-Hill, 2008.

McShane, Steven L. and Von Glinow, Mary Ann. Organizational Behavior: Emerging Knowledge and Practice for the Real World. New York: McGraw-Hill, 2010.

Mullins, Laurie J. Management and Organisational Behaviour. England: Prentice Hall, 2005. 
Mulyasa, E. Manajemen Berbasis Sekolah: Konsep, Strategi, dan Implementasi. Bandung:PT. Remaja Rosdakarya, 2003.

Pearson, Judy C., et al. Human Communication. New York: McGraw-Hill, 2008

Schermerhorn, John R Jr. et al. Organizatioal Behavior. Asia: John Willey \& Son, 2011.

Shajahan, S. and Shajahan, Linu. Organization Behavior. New Delhi: New Age International Publishers, 2004.

Silverthorne, Colin P. Organizational Psychology: In Cross Cultural Perspective. New York: New York University, 2005.

Slocum, John W. Jr. and Hellriegel, Don. Principles of Organizational Behavior Canada: South-Western Cengage Learning, 2009.

Surya Dharma. $70 \%$ kepala sekolah tak kompeten. Koran Tempo Jakarta http://www.tempo.co/read/2008/08/12/079130482/70-persen-KepalaSekolah-TakKompeten (diakses 12 Agustus 2008). 